\title{
Trends in confidence in public institutions: A comparative analysis of the Baltic countries
}

\author{
LIUTAURAS GUDŽINSKAS
}

DE

DE GRUYTER

OPEN

G

Politics in Central Europe (ISSN: 1801-3422)

Vol. 13, No. 1

DOI: $10.1515 /$ pce-2016-0020

\begin{abstract}
The paper focuses on the variation of institutional confidence in the Baltic countries. Within of framework of qualitative comparative framework, it employs a historical approach to detect causes of divergence of trust in rule of law institutions between Estonia vis-à-vis other two Baltic states. While it observes a range of variables that could affect the differences, it emphasises the role of political leadership during critical junctures, which might explain both why Estonia forged ahead at the outset of the post-communist transformation and most recent positive developments in the Baltic countries since the financial crisis in 2008-2010.
\end{abstract}

Key words: trust, courts, legal system, Baltic countries, Estonia, Latvia, Lithuania

\section{Introduction}

The post-communist Central and Eastern European (CEE) countries that joined the European Union (EU) have experienced extensive transformative changes. By establishing liberal democratic institutions and a free market economy, these countries have moved decisively towards practically implementing the principle of equal opportunities for all. Nevertheless, not all expectations have been fulfilled so far. The overall convergence of the CEE countries with Western European states is uneven and does not necessarily reflect progress. Patterns of political patronage persist, and the situation is worsening in some cases. Furthermore, widespread social and economic inequality in the region has been reinforced by the global financial turmoil that extended from 2008 to 2010 .

While GDP per capita remains the most common indicator when assessing the success of development, it provides only a partial picture. Other measures 
are often invoked, either separately or in conjunction with GDP per capita, to ensure a more precise evaluation of general conditions in a country. Some of these measures have a broadly economic character (for example, economic inequality and the unemployment rate) while others stem from a "capabilities" approach (i.e. life expectancy, infant mortality, literacy, etc.) or concern subjective evaluations of well-being (happiness-related studies and the like). To a significant extent, these alternative measures of successful development aim to evaluate the sustainability of economic progress as well as resilience in the face of various shocks and crises. Given the political and economic fluctuations in the world today, this type of analytical approach is indeed timely.

This article focuses on yet another indicator that may evidence the successful overall transformation of so-called transition societies. This indicator is the social phenomenon of trust, and more specifically, confidence in state (public) institutions. While this factor is not entirely independent (i.e. it may be tied to certain parameters of governance quality and to various structural features of society), it may have a crucial role in solidifying social support for democratic rule itself. Moreover, it may be essential if we are to ensure efficient solutions to the collective action problems that contemporary democracies face.

Among the post-communist EU member states, Estonia stands out as an exceptional case, which since its EU entry has enjoyed the highest level of confidence (and also exceeded the EU average) when its comes to the country's courts and other key administrative institutions. Furthermore, in contrast with other CEE societies, the number of Estonians who have faith in the court system has constantly exceeded the number of their compatriots who lack this trust. To explain this phenomenon, I compare the Estonian system to the most similarly designed systems in the region, i.e. those of the other two Baltic countries, Latvia and Lithuania. Formerly part of the Soviet Union, these Baltic countries have been relatively successful in transforming themselves into liberal democracies and integrating within the Western transatlantic community. All these states share many other structural features (e.g. state size, geographic location, economic model, etc.) and have engaged in cooperation in the international arena. At the same time, there are notable differences among them. In this article, I focus on divergence and fluctuations in institutional trust from the outset of the post-communist transformation of these countries. In contrast with most other comparative analyses in this area, I use a qualitative methodological approach, which may be understood as a systemic process analysis or theory-informed application of the process-tracing technique (Hall 2003).

This sudy consists of four parts. In the first section, I lay out key theoretical propositions regarding trust in state institutions and the causal relationship between this variable and other factors. The second section provides an extensive literature review of comparative research on the causes of trust-related trends in the CEE and Baltic countries; this allows me to delineate this article's contribu- 
tion to the ongoing debate. In the third part, I present and analyse noteworthy empirical data from these countries. This leads to the fourth section, which provides an interpretation of the data against the background of theoretical insights. At the same time, I consider the prospects for further research and what they may tell us about the development of the entire CEE region.

\section{Theoretical background}

Trust is defined as "a particular level of the subjective probability with which an agent assesses that another agent or group of agents will perform a particular action" (Gambetta 2000). In this sense, trust describes a trinomial relationship, i.e. a trustor, $\mathrm{X}$, expects that a trustee, $\mathrm{Y}$, will perform a particular action, $\mathrm{Z}$, in an efficient and honest way. It follows that one cannot place trust in another entity entirely, but only concerning a particular activity or group of activities.

Furthermore, we may use the model set out by Ostrom and Ahn (2009) to delineate the relationship between forms of social capital, trust and collective action (p. 23); see figure 1. According to this model, trust does not itself constitute social capital but serves as a link between particular kinds of such capital (i.e. trustworthiness, networks and institutions) and collective action. This model can help to us locate the phenomenon of confidence in the state in a general theoretical framework about trust.

\section{Figure 1: Trust, forms of social capital and their link to achieving collective action}

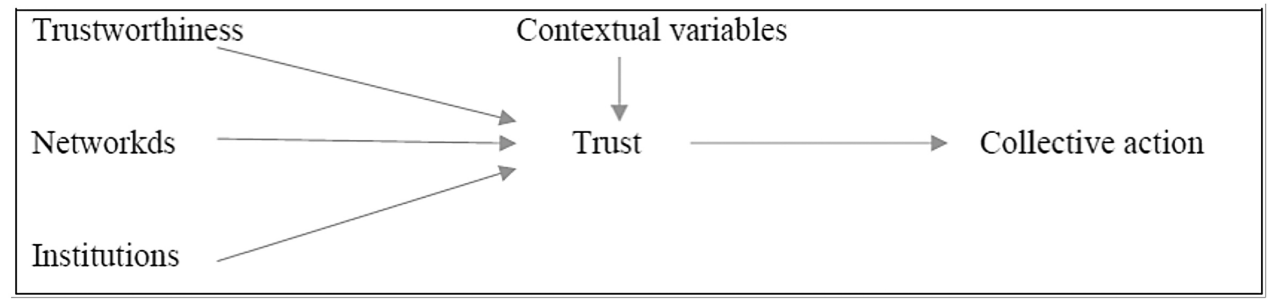

Source: Ostrom-Ahn 2009

The most basic form of social capital is trustworthiness. In today's society, however, the occurrence of this phenomenon is limited. In cases of this kind, the trustor requires considerable information about the trustee, its main patterns of behaviour and its history of cooperation. Since human interaction is far more wide-ranging today than once was the case, this type of trust is usually reserved for those who are closest to us or with whom there is an extensive cooperation history. According to Hardin (2006), there are three sources of trustworthiness: (1) the encapsulation of interests; (2) positive and reassuring psychological character traits in the trustee; (3) and moral convictions (a belief that the trus- 
tee will cooperate because of its moral nature). Hardin focuses chiefly on the first source of trustworthiness since this lays the ground for the operation of networks and institutions as the other key forms of social capital. This approach is also compatible with rational choice theory.

The encapsulation of interests refers to the trustor's assumption that its interests are bound up with the interests of the trustee. In particular, the trustor holds that the trustee is interested in continuing the cooperation. There are three ways in which these interests may be bound up. First, there may be a wish to maintain the relationship because of its practical value. Second, there may be a motive of love or friendship. And third, there may a desire to build one's reputation more generally - a goal that may be harmed by inappropriate action (Hardin 2006: 20). This reputation, thus, provides an incentive for behaving in a way that will also validate future action. As such, it transcends a single interpersonal relationship. The better the reputation an entity has, the more likely it is that other actors will be willing to cooperate with it (Hardin 2006: 24).

The other two forms of social capital have more bearing than the first one in cases of cooperation where we do not have enough information to infer the trustworthiness of the actors with whom we interact. These are, in other words, situations of "cooperation without trust" (Cook - Levi - Hardin 2005). In today's complex world, these kinds of interactions predominate. Every day we meet and need to cooperate with people we either do not know sufficiently well or interact with only once. In such cases, where cooperation must happen in the absence of trust, we require specific networks or institutions to ensure the trustworthiness of our cooperating partners.

These characterisations are also relevant when it comes to confidence in politicians and the representatives of state institutions. In most cases, the positions are not equal in these relationships, and we lack sufficient information about the true motivations and nature of these actors. Networks - and institutions in particular - are therefore crucial for ensuring our confidence in these individuals.

The distinction between networks and institutions recalls the well-established debate over whether civil society or the performance of government is essential for the effective functioning of democracy. Robert Putnam (1993) makes the case that civic associations (and networks more generally) are vital for sustaining effective democratic rule. In his view, the greater the social capital of this kind, the more likely it is that people will be able to cooperate in controlling the actions of government and so ensuring an essential public good - efficient and transparent governance. Based on this reasoning, we may assume that vibrant civic networks and a general sense of trust within a society are independent variables, while confidence in administrative and pluralist (democratic) institutions is an outcome.

This approach has, however, come under substantial criticism. Opponents have pointed out that certain networks do not necessarily care about ensuring 
that the public good extends to everyone. In fact, the core function of these networks is usually to improve the welfare of their members exclusively even if this may harm the interests of society as a whole (this recalls the debate over the prevalence of "bridging" vs. "bonding" social capital). It is instructive here to remember the notorious role played by the "early winners" of the post-communist transformation in Russia (Hellman 1998) and elsewhere: in these cases, specific networks of influential political and economic actors managed to seize significant state assets, which had the dramatic effect of undermining solidarity and trust within these transition societies.

As such, there is a case for an alternative (top-down) interpretation of the preconditions for effective democracy that puts the emphasis on the role of institutions. According to this approach, one key factor in explaining trust is the quality of governance (Kumlin - Rothstein 2005; Rothstein - Stolle 2008; Rothstein 2011). If state administrative bodies are impartial, non-corrupt and competent, we may expect that people will not only have confidence in these public institutions but the general sense of trust will be enhanced. This assertion is compatible with the model presented above (figure 1), which implies that we may trust a person despite lacking sufficient information about them if they face effective sanctions for breach of contract. It follows that the fair and proper functioning of state administrative institutions (i.e. the institutions responsible for upholding the rule of law, i.e. the courts, police, public prosecutor's office, etc.) is particularly important for fostering trust in a society. Proponents of this approach also maintain that if welfare policies (social security, education, healthcare, etc.) are implemented fairly and efficiently, particularly at the local level, people will be more willing to pay taxes to finance them. Even left-leaning citizens are more prone to evading welfare-related taxes and other state duties if they believe the misuse of state funds is likely because of the incompetence or corruptibility of state representatives (Rothstein 2011; Svallofors 2013).

For this purpose, the distinction between state (administrative) and partisan (representative) institutions is also important. We might predict that voters will not trust a parliament or other partisan political institutions that are controlled by a party or politicians with ideas contrary to these voters' own convictions. It is, however, far more worrisome when voters lack trust in supposedly neutral state (administrative) institutions.

Against this backdrop, political leadership may play an essential part in guaranteeing trust throughout a society. On the one hand, this leadership may be a source of satisfaction among citizens or even national pride if there are tangible achievements in the state's overall development, and this will, in turn, affect confidence in public institutions. On the other, the activities and leadership of politicians are among the main contributors to the quality of governance. If, however, politicians prove to be corrupt, prone to patronage and involved in public scandals that compromise their integrity, this may have a profoundly 
negative impact on not only their personal reputations but also citizens' trust in the whole political system (including state and administrative institutions).

Finally, alongside networks, political leadership and the quality of governance, there are several contextual variables that may influence general trends around trust within a state and society. Eric Uslaner $(2008 ; 2009)$ emphasises the significance of inequality in triggering mistrust among the public, which may then have implications for the spread of corruption. According to this premise, outside of issues related to the fairness of the legal system and regulatory burdens, the roots of corruption are largely non-institutional. As such, the key factor is economic inequality, which breeds a general atmosphere in which people mistrust one another. This explanation may be especially apt in post-communist societies, which, despite their overall economic progress, have experienced widening inequality since the beginning of their transformation.

According to Uslaner (2009), inequality encourages corruption since people tend to believe that the system is biased against them and that they must depend on some other entity. Furthermore, they are pessimistic about the future, which in turn undermines the incentives for behaving honestly with others. The pursuit of fairness in the court system also comes under enormous pressure under such conditions.

Other structural factors that distinguish members of a society may also shape general trends regarding confidence in the state. In the case of the Baltic countries, we should particularly consider the role of ethnic divisions. This ethnic heterogeneity is especially significant in Latvia and Estonia where the Russian-speaking population forms a large part of the population and is the main source of the cleavage in party politics. Given the existence of sizeable minorities (totalling up to $10 \%$ of the overall population) that have not yet been granted full citizenship rights in these two countries, we may assume that there are acute societal tensions that could crucially influence perceptions of the fairness and effectiveness of state institutions. On the one hand, members of these ethnic minorities may feel more disenchanted and suspicious of a state that does not guarantee equal political and civil rights among the population. On the other, nationals may be more supportive of the institutions of their newly independent democratic states, perceiving them as a key tool for securing both domestic ethnic dominance and independence from Russia as a former colonial power in the region. On this basis, we may expect to observe greater confidence in state institutions among the national majorities in Latvia and Estonia than is the case in Lithuania where the ethnic split is far less politically salient. Indeed, partly because of Lithuania's relatively homogenous population, the normative evaluation of the country's communist regime - and not its ethnic divisions - is the most critical factor shaping current party politics (Ramonaitè et al. 2014). Given this background, we may hypothesise that institutional identification with the former communist regime (rather than with the present democratic 
system) affects overall trends in confidence in the institutions of the newly democratic states.

\section{Literature review}

Comparative sociological surveys that collect data on institutional confidence have been conducted in the CEE countries since the start of the post-communist transformation. Of the earliest of these surveys, the European Value Survey, New Europe Barometer and New Baltic Barometer must all be mentioned. Since the EU's eastern enlargement in 2004, trust in various institutions in the CEE countries has also been measured in standard annual Eurobarometer reports. Moreover, the European Social Survey provides valuable comparative data on the topic. As this empirical material has gradually increased, analyses have begun to consider the causes of variations in trust across the CEE countries. Most of these efforts have tried to evaluate which of the three general emphases mentioned above, i.e. quality of government, general sense of trust or socio-structural features, is most useful for explaining societal attitudes to both partisan and administrative institutions.

Based on their research into trends in institutional confidence in the young CEE democracies from 1991 to 1998, Walter Mishler and Richard Rose (2001) concluded that the most influential factor vis-à-vis trust in institutions was the perception of their impartiality and transparency. Other important variables explaining variations were positive evaluations of macroeconomic indicators and the presence of sufficient institutional guarantees of personal freedoms (Mishler - Rose 2001). In a later publication including more recent New European Barometer data, the same authors confirmed that politicians and civil servants could most efficiently boost institutional confidence by eradicating corruption and improving the macroeconomic situation (Mishler - Rose 2011).

Jonas Linde (2012) also analysed data from New Europe Barometer along with Transparency International's Global Corruption Barometer. On this basis, he asserted that while the average level of public support for democracy in the CEE countries was around $60 \%$, only $30-40 \%$ of people were satisfied with the operation of democracy. Linde also found a strong correlation between satisfaction with the functioning of democracy and public perceptions that representatives of state institutions treated all citizens fairly and that the corruption level was low.

Meanwhile, Gabriela Catterberg and Alejandro Moreno (2006) observed trends in trust in both partisan and administrative institutions across eighty societies, including three Baltic countries, based on the data from the World Value Survey and European Value Survey (1981-2000). According to these authors, the most critical factors affecting institutional confidence were the general level of trust, people's perceptions of their own financial capabilities and their 
interest in politics and assessment of whether the government was responding to everyone's interests or favouring elite groups (Catterberg - Moreno 2006).

Kadri Lühiste (2006) also reported several findings concerning trends in institutional confidence from the $2001 \mathrm{New}$ Baltic Barometer survey. In particular, she found evidence of a strong correlation between trust in political institutions and the general level of trust in a society. Lühiste also confirmed the relationship between this kind of trust, satisfaction with economic conditions in a country and the perceived level of corruption. By analysing data from the European Social Survey 2004-2005 across twenty-four countries, including some states from the CEE region, Kimmo Grönlund and Maija Setälä (2012) also explored the relationship between overall trust and confidence in institutions such as parliament and the legal system. While these authors confirmed the existence of this link, they singled out the fight against corruption as the primary factor contributing to institutional trust. Moreover, they maintained that a key issue here was the degree of civil servants' impartiality when dealing with citizens (Grönlund - Setälä 2012).

Commenting more recently, Tom van der Meer and Armen Hakhverdian (2017) have noted that the reduction of public sector corruption has been far more influential in increasing trust in political institutions than relevant changes to macroeconomic indicators such as economic growth, unemployment, inflation, the budget deficit or income inequality. This finding is consistent with the central insight of the quality-of-government theoretical framework, which holds that an institution's processes affect public trust more than that institution's actual output (Rothstein 2011).

Analysing data from the European Social Survey in 2010, Zsolt Boda and Gergö Medve-Balint (2014) also conclude that there is no significant difference between Western European countries and CEE countries as regards the link between personal wealth and trust in institutions. On the whole, however, these authors note quite a strong tie between income inequality and the degree of institutional confidence (Boda - Medve-Balint 2014). Finally, in an analysis of trust in the court system across forty-two countries based on World Value Survey data (1995 -2002), Marc Bühlmann and Ruth Kunz (2011) demonstrate that confidence in the court system mostly depends on the actual independence of judges from political interference. This finding supports the idea that only courts that are adequately protected from political influence can garner public trust in their impartiality and competence.

To summarise this literature review, we may conclude that there is extensive evidence to confirm the impact of the quality of government on trust in partisan and administrative institutions in the CEE region, including the Baltic countries. This study aims to deepen this causal inquiry by establishing when and how the Baltic states began to diverge as regards public confidence in courts and other administrative institutions. 


\section{Empirical trend}

Several surveys consider trends in confidence in various public institutions in the Baltic and other CEE countries. The Eurobarometer results cover the longest time period, drawing on data collected twice yearly since 2004. Of the state (administrative) institutions for which public confidence is measured, the most relevant ones for our purposes are the legal system and the police. The data clearly shows the superior position of Estonia in comparison with its Baltic and other post-communist counterparts when it comes to confidence in both of these institutions (see figures 2 and 3).

Moreover, the results indicate that Estonia has the best results concerning trust in the police and the legal system across any of the post-communist EU member states. In this respect, the country exceeds the regional average by around $20 \%$ and even surpasses the EU average slightly. Meanwhile, confidence in these public institutions in Lithuania and Latvia stands at around the CEE regional average. On this count, however, it must be noted that the Lithuanian indicators have seen more fluctuation. Before 2008-2009, the country's results were below the mean rates for other post-communist EU member states. Since then, however, they have improved steadily and come to exceed the CEE average. This progress in the space of a few years is quite remarkable. Lithuanians' trust in the legal system has increased by $17 \%$ while their confidence in the police has risen by as much as $31 \%$. In contrast, in Latvia and most other CEE states, the confidence level has declined or had more limited progress over this period.

\section{Figure 2: Trust in the legal system in the Baltic countries}

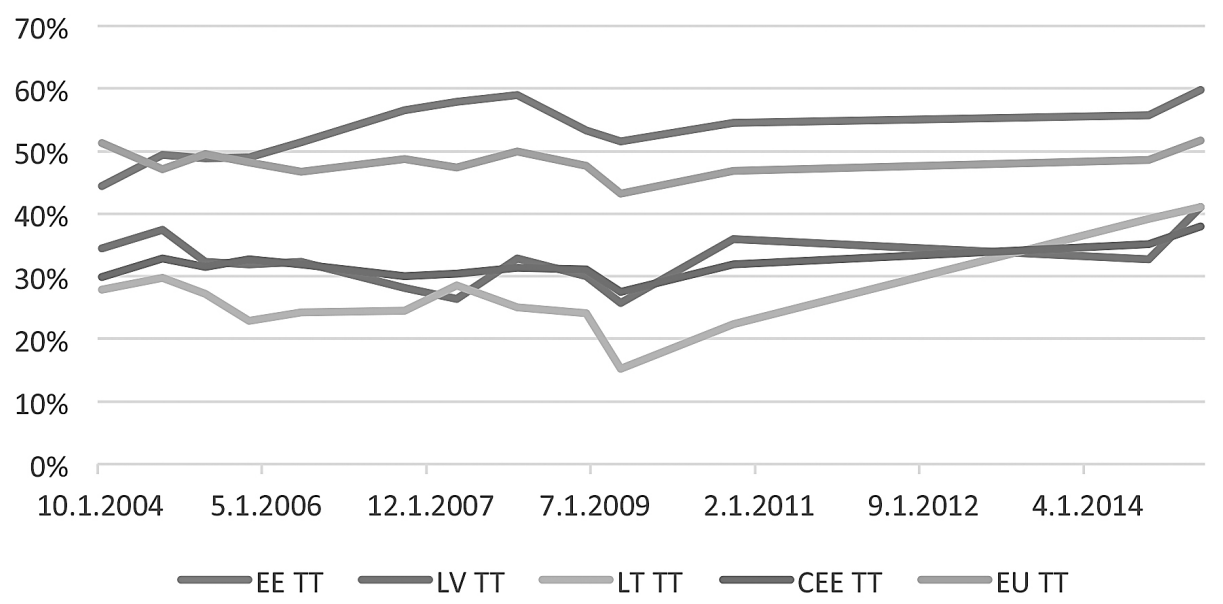

Source: Eurobarometer, 2004-2015.

Abbreviations: EE - Estonia, LV - Latvia, LT - Lithuania, CEE - Average rate for the post-communist EU-11, EU - European Union, TT - Tendency to trust. 
Figure 3: Trust in police in the Baltic countries

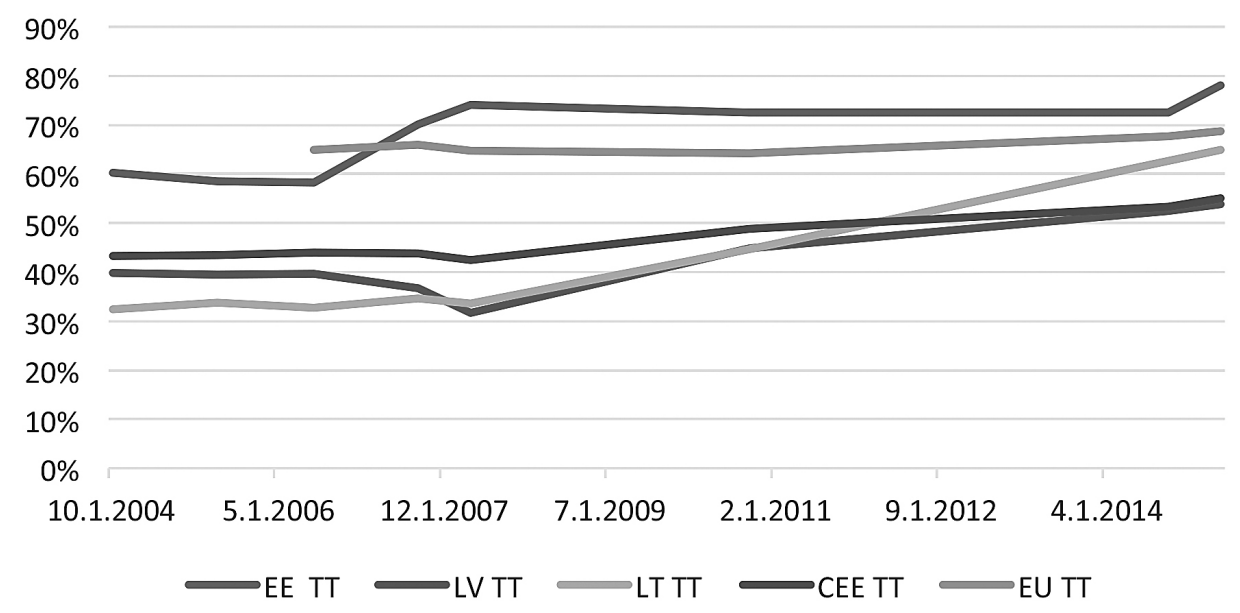

Source: Eurobarometer, 2004-2015

Abbreviations: EE - Estonia, LV - Latvia, LT - Lithuania, CEE - Average rate for the post-communist EU-11, EU - European Union, TT - Tendency to trust.

Other European surveys reflect similar trends. According to the European Values Survey (EVS), for instance, in 2008, Estonians had the highest level confidence in the legal system (54\%) and the police (68\%) among all of the post-communist EU member states. The average results for these institutions in the region were $37 \%$ and $51 \%$, respectively; see table 1 .

The European Social Survey (ESS) also confirms these observations; see figure 4. Although this survey has not always included all CEE countries, the trends again appear similar to those detected by the previously mentioned polls.

Table 1: Confidence in administrative institutions in the EU-11 MS

\begin{tabular}{|ccccccc|}
\hline Confidence & \multicolumn{3}{c}{ Justice system, \% } & \multicolumn{3}{c|}{ Police, \% } \\
Bulgaria & 1990 & 1999 & 2008 & 1990 & 1999 & 2008 \\
Croatia & 45 & 28 & 18 & 46 & 47 & 33 \\
Czech Rep. & 44 & 35 & 19 & & 53 & 37 \\
Estonia & 33 & 23 & 35 & 39 & 33 & 42 \\
Hungary & 60 & 45 & 54 & 19 & 34 & 68 \\
Latvia & 36 & 47 & 39 & 51 & 45 & 51 \\
Lithuania & 39 & 19 & 44 & 20 & 40 & 54 \\
Poland & & 42 & 44 & 28 & 26 & 45 \\
Romania & 48 & 40 & 42 & 45 & 55 & 58 \\
Slovakia & 45 & 36 & 36 & 40 & 44 & 55 \\
Slovenia & & 44 & 47 & & 50 & 53 \\
Average & 44 & 36 & 37 & 36 & 43 & 51 \\
\hline
\end{tabular}

Source: European Values Survey 
Figure 4: Trust in administrative institutions

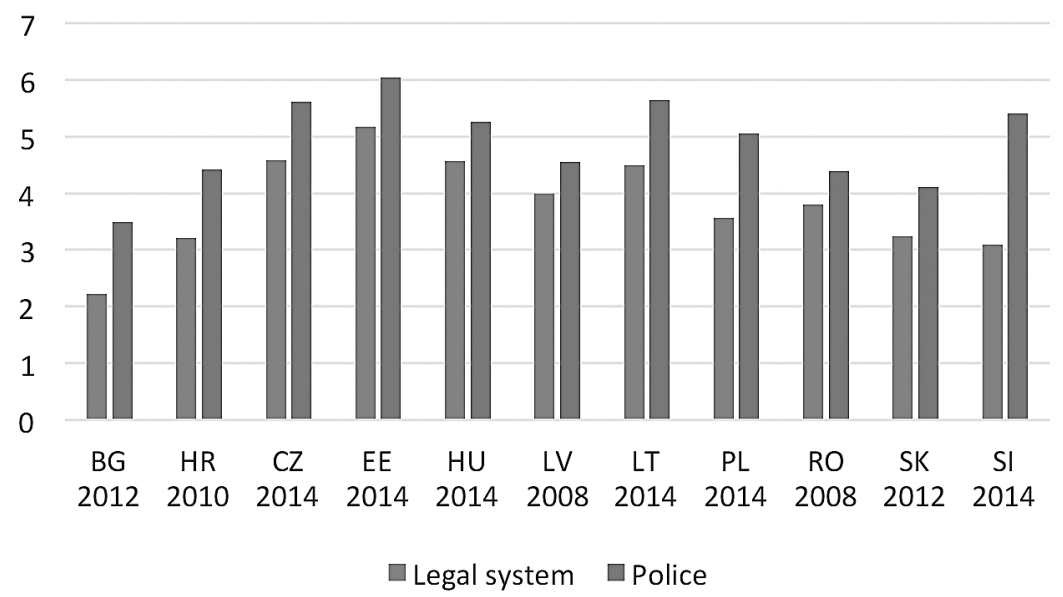

Source: European Social Survey

When asked to rate their trust in the legal system and the police on a scale from 0 (no trust) to 10 (complete trust) in the seventh and last ESS wave (2014), Estonians recorded average scores of 5.2 and 6, respectively, which were the highest ratings among the CEE countries. In the five previous ESS waves in which Estonia participated (i.e. the surveys since 2004), trust in the legal system in the country varied from 4.9 to 5.2 while it ranged from 5.5 to 6.2 for the police; these were again the highest scores in the CEE countries across any of these surveys. In Lithuania, in contrast, the level of popular confidence in administrative institutions in 2010 was one of the lowest for the CEE countries (Lithuania's legal system and police received only 3.1 and 4.5 points, respectively). Since then, there has been notable progress, with trust in the legal system rising to 4.5 points and trust in the police reaching 5.7 points in the most recent (2014) ESS survey. This trend aligns with similar developments in the Eurobarometer surveys mentioned above. In the case of Latvia, on the other hand, the only measurable (ESS) data comes from 2008. As such, we cannot infer very much about the development of trust in public institutions in this country based on the ESS.

So far, we have mostly discussed fluctuations in trust since the 2004 EU eastern enlargement. On this basis, we may deduce that Estonia's relative strength in achieving public trust in the country's administrative institutions stemmed from processes already evolved before the EU accession. In fact, however, previous EVS waves (1990 and 1999; see table 1) would suggest that Estonia did not have any such advantage. Furthermore, in 1990, Estonians had the lowest level of confidence in the country's public institutions of the citizens of all CEE nations, 
with similar scores to those in the other two Baltic countries. Arguably, this was connected with the fact that the Baltic nations (unlike the other CEE states) were not entirely free at the time; as such, citizens of the Baltic countries usually associated these administrative institutions with the repressive Soviet apparatus.

By 1999, however, the situation had changed, and these shifts in trust ratings might, thus, reveal how the fledgling Baltic states succeeded in ensuring citizens' confidence in administrative and other public institutions. At the very least, the findings from the 1999 EVS wave indicate that both Estonia and Latvia were achieving better results at this point than their southern counterpart. Confidence in the justice system in Lithuania had dropped by a dangerous $20 \%$ from the 1990 result, while it remained virtually unchanged in Estonia and had actually increased by $11 \%$ in Latvia. In the case of confidence in the police, the level in Lithuania remained more or less the same as that in 1990, while both Latvia and Estonia saw notable increases of $20 \%$ and $15 \%$, respectively (see table 1 ).

To assess the divergences across the Baltic states in the $1990 \mathrm{~s}$ in greater depth, we require more comparative data from this period. Some evidence is offered by regional surveys such as the New Baltic Barometer (NBB), which was conducted repeatedly throughout that decade.

The importance of this survey lies not only in its early date but in the opportunity it provides to assess political and social attitudes across different ethnic groups. The first NBB wave, which was conducted from September to October 1993, revealed substantial differences both among the nationals of the different Baltic states and between those groups and ethnic minorities; see table 2 .

Table 2: Trust in state and administrative institutions

\begin{tabular}{|ccccccccc|}
\hline & Est & Latv & Lith & Average & Est Ru & Lat Ru & Lit Ru & Lit Pol \\
Courts & 58 & 54 & 45 & 53 & 52 & 47 & 52 & 57 \\
Police & 46 & 38 & 44 & 42 & 38 & 37 & 49 & 51 \\
Army & 69 & 63 & 53 & 62 & 41 & 39 & 50 & 62 \\
State security & 49 & 34 & 36 & 40 & 34 & 31 & 44 & 41 \\
\hline
\end{tabular}

Source: New Baltic Barometer, September-October 1993.

$N B$ : The figures provided are the sums of those reporting considerable or some trust in the relevant institutions.

This data shows that as early as 1993, Estonians had greater confidence in the state and its administrative institutions than was the case for respondents from the other Baltic nations. Furthermore, Lithuanians scored lower than other Baltic nationals when it came to trust in the courts and the army. The differences among the Baltic nations concerning confidence in the police were not as notable as those related to the courts and the military. Nevertheless, both Latvians and Lithuanians reported far less trust in state security than was the case in Estonia. At the same time, Latvians' confidence in the courts and the army was closer to the level in Estonia than the one in Lithuania. Other important differ- 
ences concerned the trust of Russian-speaking and - in the Lithuanian case Polish-speaking residents in administrative institutions. These differences were most substantial in Estonia, where they applied especially to confidence in the army and state security (with ethnic minorities reporting lower levels of trust than Estonian nationals by $15 \%$ and $18 \%$, respectively); the effects were less marked for confidence in the courts (6\% lower for ethnic minorities) and the police ( $8 \%$ lower for ethnic minorities). In Latvia, similar trends were observed for the level of confidence in the courts (7\% lower for ethnic minorities) and in the army (14\% lower for ethnic minorities). In Lithuania, in contrast, these proportions were inverted; in most cases, respondents from ethnic minorities reported a higher level of trust in the state and its administrative institutions than the levels for nationals.

A similar survey was conducted in November 1996; the results are set out in table 3.

\section{Table 3: Trust in administrative institutions}

\begin{tabular}{|ccccccc|}
\hline & Estonians & Est Ru & Latvians & Lat Ru & Lithuanians & Lith Ru \\
Courts & 63 & 44 & 50 & 53 & 31 & 40 \\
Police & 57 & 38 & 41 & 45 & 34 & 33 \\
Army & 40 & 16 & 36 & 28 & 27 & 24 \\
Civil service & 72 & 32 & 41 & 52 & 46 & 44 \\
\hline
\end{tabular}

Source: New Baltic Barometer, November 1996.

NB. Figures indicate respondents who declared complete and general trust.

Compared with the earlier survey, these findings revealed a wider gap between Estonians and the nationals of the other two Baltic nations. Moreover, there remained a split between Estonia's Estonian- and Russian-speaking populations when it came trust in administrative institutions. Meanwhile, except in the case of the civil service, Latvians appeared to be more inclined to trust in administrative institutions than was the case for Lithuanians. On the other hand, in both Latvia and Lithuania, ethnicity did not seem to have a significant impact on confidence in these institutions.

The results of the 1993 and 1996 NBB surveys suggest that Estonians were already becoming more trustful of their administrative institutions in the early phases of transformation. This would seem to contrast with the picture for residents of the other two Baltic nations. However, another report from November-December 1992 indicates a rather different situation. These findings are summarised by Anton Steen (1996); see table 4. 
Table 4: Confidence in institutions (\%)

\begin{tabular}{|ccccc|}
\hline Institutions & Estonia & Latvia & Lithuania & Average \\
Legal system (courts) & 23 & 21 & 23 & 22 \\
Police & 28 & 24 & 32 & 28 \\
Civil service & 29 & 19 & 25 & 24 \\
\hline
\end{tabular}

Figures for the categories "quite a lot of confidence" and "a great deal of confidence" are combined; November-December 1992

Source: Steen 1996: 211

As the table shows, there appear to have been no significant differences among the Baltic populations regarding trust in administrative institutions (putting aside the somewhat lower results for Latvia in general). Moreover, Steen (1996) argues that "the group with the lowest confidence in institutions comprises people with higher education. No other independent variable has such a systematically negative effect on confidence in institutions" (p. 223). As such, he interprets this data as confirmation of the hypothesis that people with a higher education are better informed about the state of affairs in their country, and thus, more critical of its institutions. This conclusion is similar to the one reached by Miller (1993), who asserted that as early as 1990, younger people, and particularly those with a higher education, felt alienated from the Soviet system in Lithuania (as well as in Russia and Ukraine) (cf. Steen 1996: 217).

The autumn of 1992 was indeed still early days in the formation of the new states and, thus, despite the democratisation that was already under way, residents may have eyed administrative institutions suspiciously as means of continuing the former regime. Nevertheless, as we have seen, the NBB suggests that there were notable improvements in Estonia in 1993 regarding the level of confidence in the country's administrative institutions and that this contrasted with the situation in the other two Baltic countries. This leads us to the question of what exactly happened during this period in this northernmost Baltic state.

\section{Discussion}

In the first part of this study, I outlined three main lines of argument about the factors that may influence trends around confidence in institutions. One set of reasons emphasises political and institutional variables that fall under the general category of quality of government. This describes a mostly top-down process in which a key factor may be the success of political leaders in imposing reforms that lead to transparent, fair and efficient institutional operations. These actions may, in turn, encourage people to give more credit to a new reformed mode of governance. Conversely, if a government is corrupt and serious scandals rock the entire political system or it is beset by shocks and crises, this may seriously undermine confidence in representative and administrative institutions. Another explanation stems from a bottom-up approach. This stresses the role 
of networks in actually controlling the government and so ensuring trust in its institutions, including those responsible for maintaining order within a society. The strength of civil society is usually associated with a high level of overall trust in the community as well as egalitarian values that promote horizontal relationships both among a nation's people and between them and the state. Last but not least, there are important structural differences in a society which may also affect how people trust each other as well as whether they feel fairly treated by state institutions. Among these divisions, we should highlight both economic inequality and the degree of ethnic fragmentation. In many post-communist societies, there is also a salient split between supporters of the current democratic regime and those who remain nostalgic for the former one. Significantly, this division may point to profound socio-psychological alienation within certain segments of society vis-à-vis the current political system. This could itself negatively affect confidence in administrative and other public institutions.

In this section, I present some evidence to determine which of these explanations is most appropriate for analysing trends in confidence in administrative institutions in the Baltic states. To evaluate the top-down approach, as set out above, we must pay heed to the period when the noted divergences occurred. While the picture is fragmented due to a lack of regular comparative surveys at that time, there is a good reason to focus on the 1992-1993 period. As we have observed, it was precisely at this time that Estonians became more trusting than people in other Baltic states of their country's administrative institutions. According to the premises set out above, there must have been some essential reforms to these institutions which made them more transparent and efficient, and thus, also more trustworthy. In fact, there is some evidence to support this explanation.

When Mart Laar's government came to power in Estonia after the first post-independence parliamentary elections in September 1992, sweeping reforms began across many public sectors. Although Laar is famous worldwide for his "economic shock therapy" and its achievements, his government also introduced radical changes to the legal system and its operations. To begin with, the entire judiciary was appointed anew. Although this reform had been outlined earlier, the appointment process only commenced after the 1992 parliamentary elections. Given the staunchly anti-communist ideology of the parliamentary majority, the key political criterion for the approval of Supreme Court judges was their non-involvement in political cases under Soviet rule. The newly formed Supreme Court was then authorised to nominate the remaining magistrates to be appointed by the President. At the same time, the reform increased the actual number of judges. Previously there had been eighty-three judges in Estonia. As of 1 May 1994, however, a total of 154 judges had been appointed, and there were still some vacancies to be filled (Kalniņš 2015:13-14). According to the account of the then chairperson of the Riigikogu Legal Committee Daimar Liiv: "[B]y the end of 1995 maybe a half of [former Soviet judges] stayed [in their positions]. 
The idea was that they were not establishing the culture for the judiciary. The culture was established by the Supreme Court" (quoted in Kalniņš 2015:13-14).

There were also corresponding developments in the civil service. Alongside the replacement of its Soviet-era cadres (under a reform admittedly somewhat less radical than the one to the legal system), there was a clear political will to downsize and simplify the overall government machinery. Under a 1992 coalition agreement, the primary tasks for government reformers were reducing the large number of ministries, bringing various subordinate organisations under ministerial control and slashing the public sector by one third (Sarapuu 2012: 812). While the actual implementation of these goals was not entirely consistent, the initial 1993-1995 structural reform led to the de-institutionalisation of the entire public administration system, thus helping to break ties with the Soviet past. This also had critical implications for the reshuffling of personnel. In 1994, employees under the age of thirty comprised $31 \%$ of staff at the Ministry of Finance, $28 \%$ of staff at the Ministry of Justice and the Ministry of Defence and 48\% of staff at the Ministry of Foreign Affairs (Randma 2001: 43). It has been claimed that fewer than half of the government's employees in 1992 remained in the same occupation in 1997 (Titma et al. 1998: 126). According to one account from 2007, the overwhelming majority (77\%) of Estonian civil servants entered the service during the independence years and so were not part of the Soviet administrative system (Tõnnisson - Randma-Liiv 2008: 103).

The initial "de-sovietising" reforms to the governing system also made it more receptive to international influences which could then shape its development (Sarapuu 2012). Indeed, of the post-communist CEE countries, Estonia implemented the most radical reforms, and to a large extent, these were based on a New Public Management (NPM) approach (Nemec 2008). Generally, NPM-based policy changes met with only mixed success in the CEE region (Dreschler 2005; Nemec 2008). However, in the Estonian case, combined with the de-sovietisation of judicial and administrative personnel at the start of the transformation process, these reforms lifted the country to the top of the corruption control rankings in the CEE region and beyond (as evidenced by the measures of both Transparency International and the World Bank). The Estonian advantage over the other two Baltic countries was striking from the time of these states' inclusion in these rankings. In the 1999 Corruption Perception Index, for instance, Estonia claimed twenty-seventh place of the ninety-nine countries analysed, while Latvia and Lithuania were ranked only fiftieth and fifty-seventh respectively (Transparency International 1999).

Neither Lithuania nor Latvia saw an overhaul of their civil service and legal systems at the outset of the transformation process of the kind that occurred in Estonia. The different composition of the political leadership in these states may explain this situation. After the first post-independence democratic parliamentary elections in Lithuania in October 1992, the former communist forces headed 
by Algirdas Brazauskas won a decisive victory, claiming an absolute majority in parliament (Seimas). While these forces followed the advice of the International Monetary Fund and other international institutions and so carried out neoliberal economic reforms at a similar pace to those in Estonia, they were (quite understandably) not as keen to pursue the de-sovietisation of the state apparatus. In fact, Estonia was itself ruled by governments with a similar profile, headed by Tiit Vähi and subsequently Mart Siimann, in the 1995-1999 era. These regimes were, however, both too short-lived and not reactionary enough to reverse many of the effects of the reforms of the earlier period (Kalniņš 2015: 29). In Latvia, on the other hand, right-centrist political forces prevailed in the country from the time of regained independence, exercising even more power than they did in Estonia without any strong opposition from the left. Nevertheless, the degree of state capture and oligarchisation in Latvia was notably higher than that in any other Baltic state (Auers 2015), and this may itself have seriously impeded the building up of trustworthy public institutions. The roots of these developments trace back to the early $1990 \mathrm{~s}$ when informal politico-business networks (such as "Club 21") critically shaped the evolution of Latvia's political parties, thus undermining the impartiality of privatisation and other essential economic reforms (Bennich-Björkman 2006). Another important factor aiding the spread of corruption in Latvia was the limited political competition. This resulted mainly from the ethnic split, which restricted the powers of the opposition parties to control the government (Grzymala-Busse 2007).

As the data in the second part of this study suggests, for most of the time since the start of the transformation process, Lithuania has recorded the lowest levels of confidence in its administrative institutions across all the Baltic countries. Nevertheless, there has been a steady increase in Lithuanians' trust in both the national courts and the police since 2009. While a deeper causal inquiry remains necessary, we may surmise that one potential explanation is the impact of measures taken by President Dalia Grybauskaite to increase the transparency and effectiveness of the legal system and other administrative institutions. In fact, this goal has been one of Grybauskaite's top priorities since the start of her rule. A political independent, Grybauskaite was initially elected with a huge majority back in 2009 and she has continued to enjoy convincingly high approval ratings in her second term of office since 2014. While reforms to the police and public prosecutor's office initiated by her appointees have met with some controversies (though mostly of a managerial kind), the President has persistently worked to promote an image of herself as a non-partisan guardian of the rule of law and an active fighter against political corruption. In line with legislative initiatives to eradicate corruption in areas ranging from the energy sector to party financing, Grybauskaite has put some effort into improving the reputation of the court system. According to data from the President's office, during the first six years of her rule (2009-2015), seventeen judges were dis- 
missed for discrediting the good name of the judiciary; in comparison, there were only fourteen such cases for the entire 1990-2009 period (Office of the President of the Republic of Lithuania 2015). ${ }^{1}$ In this semi-presidency, the President, who enjoys a high approval rating and significant powers (though not the right to dismiss the Prime Minister), is proving to be a key part of the overall checks-and-balances system. In elitist post-communist societies where there is significant distrust of pluralist institutions such as political parties and parliament, a directly elected president who keeps parliamentary democracy in line may be the main way of ensuring the political stability and legitimacy of the state and its institutions.

As we have seen, one alternative to the quality-of-government approach asserts the importance of civic networks and cultural features that foster more trustworthy institutions. It should, however, be emphasised that these two approaches are not necessarily in conflict. To the contrary, they may prove to be complementary and offer a more encompassing understanding of how trust may be developed in post-communist societies where the state must be rebuilt as a "ship in an open sea" (Elster - Offe - Preuss 1998).

Indeed, there is some evidence that even at the start of the post-communist transformation, Estonian society had certain traits that made it more amenable to evolving trust in liberal democracy and its public institutions than the other two Baltic states. Analysing data from 1990 World Value Survey (including the EVS results cited elsewhere in this study), German researcher Katrin Mattusch (1997) summarises:

Lithuanians [...] take guidance from traditional values in family life, are personalistically orientated, fairly authoritarian, have high demands of equality for the community, believe that one can achieve little in life and society by her/his efforts and are less disposed towards capitalist ideas of property and distribution. Estonians are more secularised; they conceive family roles in a less traditional way and display the individualistic, autonomous, and achievement-orientated understanding of their role in society. They have interiorised to a lesser degree the requirements of equality (although they accustomed themselves to the socialist provision state too). They provide more support for the capitalist ideas of management and differentiation. On all of these fundamental value ideas, Latvians take the middle position between Lithuanians and Estonians. It seems that this culture is characterised by the mixture of different traditions (pp. 81-82; translation in Norkus 2011: 29-30).

1 See https://www.lrp.lt/lt/spaudos-centras/pranesimai-spaudai/prezidente-skaitys-sesta-metini-pranesima/22880 (7 June 2017). 
Zenonas Norkus $(2008 ; 2012)$ has traced the origins of these attitudes back to the eighteenth and nineteenth centuries when the Lutheran Pietist Herrnhuter movement extended its missionary activities across Estonia and some parts of Latvia. Following a classical Weberian Protestant thesis, Norkus contends that these culturally rooted values allowed Estonians to adapt faster and more effectively to the rules of market capitalism than was the case for the residents of the other two Baltic nations after the breakdown of the Soviet Union. These insights may also shed light on the variations across Baltic societies regarding their abilities to build a reliable and inclusive democratic state. We may expect that when emancipation-based values are more widespread in a society, there will be more support for liberal democracy and the institutions responsible for its implementation. Additionally, as the people living in these more liberated circumstances feel freer of various exclusionary frameworks, there should also be a higher level of overall trust in the society, which, according to Putnam's (1993) original interpretation, is conducive to the proper functioning of democracy.

A 1995 NBB survey showed that the differences among the Baltic nations concerning overall levels of trust in society followed the direction of their confidence in state institutions, albeit to a lesser extent. Lithuanians reported the lowest level of trust in their dealings with other people (with a result of only $15 \%$ ), while Estonians and Latvians were more trustful of others, with scores of $23 \%$ and $24 \%$, respectively. Even so, it should be noted that there were no great differences between the nationals of Baltic states and their Russian-speaking ethnic minorities. In fact, in both Latvia and Lithuania, these Russian-speaking residents proved to be slightly more trusting than nationals. The 1996 NBB findings showed similar trends. On the other hand, the surveys conducted in 2001 and 2004 revealed a different situation. According to these investigations, Lithuanians had the highest levels of trust among residents of the Baltic states (44\% in 2001 and 54\% in 2004) followed by Latvia (39\% and $42 \%$ respectively) and Estonia (31\% and 44\%). The levels of trust reported by Russian-speaking ethnic minorities were similar to those of nationals.

In contrast with the findings of NBB surveys from the $1990 \mathrm{~s}$, a rather dramatic upswing in societal trust was evident across all three Baltic countries during the first half of the $2000 \mathrm{~s}$. We may hypothesise that this was triggered by rapid economic growth and successful integration into key Euro-Atlantic organisations, which should have reduced the tensions within these societies. However, as we have seen, attitudes to the democratic regime and its institutions tended to be far stickier. Latvia's position was also rather puzzling. If individualist values are important for developing democratic and market institutions, then we might aexpect Latvia to fare better than Lithuania with regard to both economic growth and state transparency. This, however, was not the case.

One potential solution to this conundrum is offered by Li Bennich-Björkman (2007), whose analysis also suggests how we might combine cultural and 
institutionalist approaches to explain variations in institutional trust across the Baltic countries. Bennich-Björkman contends that the type of regime in power may have a long-term impact on the evolution of its public networks. At the same time, however, she shows that these networks also play a role in building up the new state when windows of opportunity open up. To make the case, Bennich-Björkman starts from the interwar period, connecting a rather mild version of Konstantin Päts's dictatorship, which was installed in 1934, with vibrant civic traditions and a relatively developed economy. This makes for a rather stark contrast with Lithuania, where Antanas Smetona's more repressive regime had ruled the mostly agricultural and conservative country since 1926. This comparison overlaps with the even more historicist account put forward by Norkus (see above). Bennich-Björkman, however, focuses on how these civic traditions in interwar Estonia were translated into public life under Soviet rule. In her view, since the time of Khrushchev's détente, a gradual revival has been under way of various mostly informal civic organisations which originated in the academic circles of Tartu University and among the members of Tallinn's intellectual strata and were responsible for Estonia's cultural heritage, language, natural world, etc. Furthermore, Bennich-Björkman (2007) shows how the resulting underground movements such as Tôru, Kodulinn and Noor Tartu consequently formed a viable counter-elite including figures such as Mart Laar, Trivimi Velliste, Marju Lauristin and the like, who then effectively led the reformist post-independence agenda. In Lithuania, there were also signs of influential anti-Soviet resistance networks. However, these networks were more dispersed (in addition to some secular cultural non-governmental movements, the Catholic Church played an important role). Moreover, they were subdued by local Communists, who oversaw an intensive industrialisation and urbanisation programme, and thus, enjoyed greater public support than existed in any other Baltic country.

The Latvian case was perhaps the most dramatic. Since the country's socio-economic development and political regime in the interwar years more closely resembled the Estonian path than the Lithuanian one, we might expect there to have been a similar re-emergence of underground civic movements to the one seen in Estonia when the most brutal period of Stalinist rule eventually ended. This, however, did not happen. Instead, these Latvian networks were more controlled and repressed by the Soviet regime than was the case in any other Baltic country. According to Bennich-Björkman, this was an effect of Soviet attitudes to Latvia. In fact, the country was the site of the Soviets' most extensive purge of national Communists in the $1960 \mathrm{~s}$, and they also founded a military centre for the whole Baltic region there, thereby implying Latvia's fundamental strategic importance to the Kremlin and its tighter control over the state (Bennich-Björkman 2007). This would have clear repercussions after the collapse of the Soviet Union. In contrast to their Estonian counterparts, Latvian reformist 
forces were less organised and united, thus creating more opportunities for pragmatic actors to take the lead in the overall transformation process and so subvert it partly to serve their particular interests (Bennich-Björkman 2006).

A third and final line of reasoning based in our conceptual model analyses the role of contextual factors, focusing on the main societal divisions and their impact on variations in trust in these post-communist countries. I have concentrated on three politically salient cleavages for the purpose of this inquiry: socio-economic inequality, ethnicity and evaluations of the post-communist past.

Starting with the last of these divisions, the 1993 New Baltic Barometer reveals rather stark differences among the Baltic nations regarding their support for the democratic regime. Among ethnic Lithuanians, there was an even balance between democrats (i.e. those who approved of the current regime and disapproved of the system before independence) and reactionaries (i.e. those with the opposite positions), with each camp receiving $27 \%$ of support. Among nationals from the other Baltic states, the democrats prevailed over the reactionaries. In Estonia, the results for the two sides were $41 \%$ versus $14 \%$, while in Latvia, the gap was smaller: $27 \%$ to $20 \%$. Among ethnic minorities, this results clearly went against the democrats, with the biggest proportion of reactionaries found in the Latvian Russian population (39\%) and the Lithuanian Polish population (42\%) (NBB 1993 - SPP-222). In consecutive NBB surveys (conducted in 1995, 1996, 2001 and 2004), similar trends remained in place. Lithuanians were the most sceptical about the advantages of the current democratic regime over the former communist system, while Estonians had the fewest reservations. It was not until 2004, the year when Lithuania's EU and NATO membership was confirmed that the country's democrats $(32 \%)$ outnumbered its reactionaries (16\%). Nevertheless, Lithuanians still lagged rather significantly behind Estonians, of whom $48 \%$ were democrats and $13 \%$ had a negative assessment of the regime change. On the other hand, among Latvians, the gap between democrats and reactionaries widened slightly, with results of $36 \%$ vs. $19 \%$. For the ethnic Russian minority in all three Baltic countries, the reactionary position continued to prevail over the pro-democrat one; the difference was biggest in Latvia (13\% vs. $38 \%)$ and narrowest in Lithuania (11\% vs. $21 \%$ ), while in Estonia, it was $11 \%$ vs. $29 \%$.

The differences observed in the ratio of democrats to reactionaries across the Baltic countries generally aligned with trends in trust in administrative institutions at that time, and could also be explained based on divergences in the communist heritage of the Baltic countries. As we have noted, the strong presence in Lithuania of residents who favoured the communist regime allowed ex-communist forces to regain power as soon as 1992. This, in turn, impeded more radical public sector reforms of the kind seen in Estonia. Even so, the last NBB survey (conducted in 2004) revealed that the balance between democrats and reactionaries in Lithuania appeared to be shifting, which might suggest that 
other causal factors had assumed greater importance concerning confidence in state institutions and other political attitudes. Nevertheless, at least as far as party politics and voter behaviour are concerned, this cleavage regarding the evaluation of the post-communist past is still seen as a dominant force in Lithuania (Ramonaite et al. 2014).

Another societal division that is of paramount importance in the Baltic countries - and in Latvia and Estonia especially - is ethnicity. Since all NBB surveys addressed this particular cleavage, we can learn quite a lot from their results (as discussed above). As we have noted, only the Estonian findings appeared to support the importance of this factor for explaining confidence in administrative institutions. Meanwhile, in Lithuania, there was no evident difference between respondents of various ethnic minorities when it came to their trust in administrative institutions. The situation of Latvia was, however, more ambiguous. While the 1993 NBB survey exposed a difference in how Latvians and Russian-speaking residents evaluated the trustworthiness of administrative institutions, the same pattern did not recur in 1996. Arguably, since the lustration of the staff of Latvian institutions was more limited than in the Estonian case, neither ethnic Latvians nor the country's Russian-speaking population had clearly formulated opinions about institutional fairness and competence. Nevertheless, NBB surveys showed there were significant differences between nationals and non-nationals across all three Baltic countries concerning their attitudes to the current regime's performance and its comparison with the former system. In these cases, ethnicity may have played a significant role in shaping how Baltic residents judged the overall regime change.

Last but not least, we have seen that income inequality in a society may also affect the trust relationships within it. According to the model proposed by Eric Uslaner (2009), since income inequality influences trust in general, it is also an indirect trigger for corruption, which could then contribute to even greater inequality. Based on this causal chain, we may also deduce that inequality could negatively affect confidence in administrative and other state institutions. Here Gini index scores do indeed show certain differences within the Baltic region. According to the Eurostat data, Estonia had the lowest average Gini index (32.3) of all the Baltic countries for the 2005-2014 period - in contrast, Lithuania's result for the same period was 34.7, while for Latvia, it was 36. 3. If we compare the evaluations of only these three Baltic countries, we find that they generally correspond with the rankings for perceived corruption and confidence in administrative institutions. At the same time, the three Baltic states rank among the most unequal societies in the EU; their Gini indices exceed not only the average EU Gini index (30.6) for 2005-2014 but also the average result for the post-communist EU member states over this period (30.5). While this outcome might be expected to some degree for Lithuania and even more so for Latvia, it is harder to explain the Estonian case with our 
theoretical model. A more balanced picture emerges, however, if consider the United Nations Human Development Index (HDI), and particularly the Income-adjusted Human Development Index (IHDI), which evaluates both the scope of public goods like education and health and their distribution in a society. In this regard, Estonia's 2014 ranking (0.861) is far higher than the results for most of the post-communist EU member states (their score was 0.834 on average). Meanwhile, Lithuania's score (0.839) comes close to the CEE average, and Latvia receives only 0.819 (UN 2015). Assuming a gradual easing in the ethnic and historical tensions in the Baltic countries, the income gap may be one of the biggest hurdles to consolidating state institutions and maintaining citizens' confidence in them in the future.

\section{Conclusions}

In the wake of global terrorism, the refugee crisis and rising political extremism, confidence in state administrative institutions and their fairness and professionalism is an essential asset. Such trust is needed both for guaranteeing social stability and the prospects for sustainable growth.

The experiences of the Baltic countries provide an interesting case study that illustrates the challenges of building up trust in transition societies. Despite the relative success of these states in achieving their main transformation goals, a lack of citizen confidence in public institutions is usually cited as a key obstacle to fighting the grey economy and developing inclusive public policies.

Notwithstanding their similar circumstances, each Baltic country has pursued its own path in seeking to create a reliable and capable state. The results have also been different. Estonia is widely seen as one of the biggest transition success stories since the third wave of democratisation began, and this is also reflected in the numbers. For more than a decade, Estonia has enjoyed one of the highest levels of public confidence in state administrative institutions of all the post-communist EU member states. Moreover, the country has also surpassed the EU average in this realm. From the data we have observed, we may conclude that Estonia's divergence from the other Baltic countries was already under way at the outset of the transformation process. The critical juncturewas the first post-independence parliamentary elections in the autumn of 1992, when anti-Soviet forces claimed a decisive victory. Headed by Mart Laar, the new government quickly embarked on a reshuffle of the state administration and legal system so as to cut ties with the former regime and its organisational culture. Together with early market reforms, these changes seem to have been fruitful. In this regard, top-down factors such as political leadership and timely governmental reforms have each played a role.

It is, however, also important to consider the impact of the former regime. Had the Soviets repressed underground civic movements in Estonia as they did 
in Latvia, the Estonian counter-elite would likely have been less united and more vulnerable to external pressures from business and other interest groups. The communist heritage must also be seen as an essential factor in the Lithuanian experience. For socio-economic and historical reasons, Lithuania's communists had more legitimacy in the eyes of the national public than their equivalents in the other two Baltic countries. This, in turn, allowed the communists to win the first post-independence parliamentary elections. Moreover, it has enabled them to run the country for most of the time since then. The permanent confrontation between left and right forces in the country's parliament reflects this key cleavage in Lithuanian party politics, i.e. the different attitudes to the communist past. Given this background, it may be argued that this persistent internal split has had a profound effect on popular support for liberal democracy and its implementing administrative institutions. This may also explain why for the entire first decade after independence, Lithuania's residents were the least trusting of all their administrative institutions among the populations of the Baltic countries.

In the other Baltic states - and in Latvia particularly - ethnicity has played a key role in structuring party politics. Even so, Estonia is the only country where there was a clear and observable link between ethnicity and the confidence expressed in administrative institutions in the $1990 \mathrm{~s}$. This may have been a consequence of the more radical de-sovietisation approach applied during the restructuring of the state apparatus. Arguably, this boosted the confidence of ethnic Estonians concerning administrative institutions but it did not affect the Russian-speaking population in the same way.

Nevertheless, given the strong economic performance and major international achievements of the Baltic countries in the $2000 \mathrm{~s}$, we might expect these identity tensions to become less salient. In this respect, we may observe a rather significant increase in overall trust in these societies. This should, in turn, bring other factors to the fore. On the one hand, there has been a steady rise in confidence in administrative institutions in Lithuania since 2009, coinciding with the initiation of law enforcement reforms by the then newly elected President Dalia Grybauskaite. On the other, Baltic societies continue to be largely unequal and affected by the net emigration rate and poverty in some parts of these states. If these issues are not tackled seriously, they may become a growing source of major source of political instability.

What lessons can we draw from the Baltic states for other countries in the region and beyond? Against the background of our general theoretical framework and the medium-term literature on the development of institutional confidence in the CEE region (to which this article has sought to contribute), we have seen the pivotal role of political leadership in raising the quality of government, notably at critical junctures (as in the case of Estonia). Where, however, this does not happen and some windows of opportunity close, competitive party politics and the balance of power between parliamentary government and a directly 
elected president, as seen in Lithuania, may also provide a way forward, at least in the medium or long term.

\section{References}

Auers, Daunis (2015): Comparative Politics and Government of the Baltic States: Estonia, Latvia and Lithuania in the 21st Century. Basingstoke \& New York: Palgrave Macmillan.

Bennich-Björkman, Li (2006): Building Post-communist States: Political Corruption and Strategies of Party Formation in Estonia and Latvia, in Kn. Sven Eliaeson (ed.), Building Democracy and Civil Society East of the Elbe: Essays in Honour of Edmund Mokrzycki. New York: Routledge.

Bennich-Björkman, Li (2007): The cultural roots of Estonia's successful transition: how historical legacies shaped the 1990 s. East European Politics \& Societies, Vol. 21.

Boda, Z. - Medve-Balint, G. (2014): Does Institutional Trust in East Central Europe Differ from Western Europe? European Quarterly of Political Attitudes and Mentalities 3 (2): 1-17.

Bühlmann, M. - Kunz, R. (2011): Confidence in the Judiciary: Comparing the Independence and Legitimacy of Judicial Systems. West European Politics 34 (2): 317-345.

Catterberg, G. - Moreno, A. (2006): The Individual Bases of Political Trust: Trends in New and Established Democracies. International Journal of Public Opinion 18 (1): 31-48.

Cook, Karen S. - Hardin, Russell - Levi, Margaret (2005): Cooperation without Trust? New York: Russell Sage Foundation.

Drechsler, W. (2005): The Re-Emergence of "Weberian" Public Administration after the Fall of New Public Management: The Central and Eastern European Perspective. Halduskultuur 6: 94-108.

Elster, Jon - Offe, Claus - Preuss, Ulrich K. (1998): Institutional Design in Post-communist Societies: Rebuilding the Ship at Sea. Cambridge: Cambridge University Press.

European Commission, Eurobarometer: available at http://ec.europa.eu/COMMFrontOffice/ PublicOpinion/.

European Social Survey: available at http://www.europeansocialsurvey.org/.

Eurostat: available at http://ec.europa.eu/eurostat.

European Values Study: available at http://www.europeanvaluesstudy.eu/.

Gambetta, Diego (2000): Can we trust trust?, in Gambetta, Diego ed., Trust: Making and Breaking Cooperative Relations, 213-237. Oxford: University of Oxford, Department of Sociology

Grönlund, Kimmo - Setälä, Maija (2012): In Honest Officials We Trust: Institutional Confidence in Europe. The American Review of Public Administration 42 (5): 523-542

Grzymala-Busse, Anna (2007): Rebuilding Leviathan. Cambridge: Cambridge University Press.

Hall, Peter (2003): Aligning Ontology and Methodology in Comparative Politics, in Mahoney, James - Rueschmeyer, Dietrich (eds). Comparative Historical Analysis in the Social Sciences, 373-404, Cambridge: Cambridge University Press. 
Hardin, Russell (2006): Trust. Cambridge: Polity Press.

Hellman, Joel S. (1998): Winners Take All: The Politics of Partial Reform in Postcommunist Transitions. World Politics 50 (2): 203-234.

Kalniņš, Valts (2015): Process-tracing study report on Estonia. ANTICORRP, Hertie School of Governance.

Kumlin, Staffan - Rothstein, Bo (2005): Making and Breaking Social Capital. The Impact of Welfare State Institutions. Comparative Political Studies 38 (4): 339-65.

Linde, J. (2012): Why feed the hand that bites you Perceptions of procedural fairness and system support in post-communist democracies. European Journal of Political Research 51 (3): 410-434.

Lühiste, K. (2006): Explaining trust in political institutions: Some illustrations from the Baltic states. Communist and Post-Communist Studies 39: 475-496.

Mattusch, K. (1997): Weltbilder als Weichensteller für die Richtung des Wandels. Zur Aktualität der "Protestantischen Ethik" am Beispiel des Baltikums, in Sterbling, A. - Zipprian, H. (eds.), Max Weber und Osteuropa. Beiträge zur Osteuropaforschung, Bd. 1. Hamburg: Reinhold Krämer Verlag.

Meer van der, T. - Hakhverdian, A. (2017): Political Trust as the Evaluation of Process and Performance: A Cross-National Study of 42 European Countries. Political Studies 65 (1): 81-102.

Miller, A. H. (1993): In Search of Regime Legitimacy, in Miller, A. H. et al., eds., Public Opinion and Regime Change. Oxford: Westview Press.

Mishler, W. - Rose, R. (2001): What Are the Origins of Political Trust? Testing Institutional and Cultural Theories in Post-communist Societies. Comparative Political Studies 34 (1): 30-62.

Nemec, Juraj (2008): Public Management Reforms in CEE: Lessons Learned, in Bouckaert, G. Nemec, J. - Nakrošis, V. - Hajnal, G. - Tõnnisson, K. eds. Public management reforms in Central and Eastern Europe, 343-372, Bratislava, Slovakia, NISPAcee.

New Baltic Barometer (1993, 1995, 1996, 2000, 2001, 2004) [Richard Rose], University of Strathclyde, Glasgow, Scotland.

Kitschelt, Herbert et al. (1999): Post-Communist Party Systems. Competition, Representation, and Inter-Party Cooperation. Cambridge: Cambridge University Press.

Norkus, Zenonas (2008): Kokia demokratija, koks kapitalizmas? Pokomunistine transformacija Lietuvoje lyginamosios istorinés sociologijos požiūriu. Vilnius: Vilniaus universiteto leidykla.

Norkus, Zenonas (2011): Estonian, Latvian and Lithuanian post-communist development in the comparative perspective, in Lauristin, Marju, ed., Estonian Human Development Report 2010/2011: Baltic Way(s) of Human Development: Twenty Years On, 22-30, Tallinn: Eesti Koostöögu.

Norkus, Zenonas (2012): On Baltic Slovenia and Adriatic Lithuania: A qualitative comparative analysis of patterns in post-communist transformation. Vilnius, Budapest: Apostrofa/Central European University Press.

Ostrom, Elinor - Ahn, T.K. (2009): The meaning of social capital and its link to collective action. In Svendsen, Gert Tinggaard - Svendsen, Gunnar Lind Haase, eds., Handbook of Social Capi- 
tal: The Troika of Sociology, Political Science and Economics. Cheltenham \& Northhampton: Edward Elgar.

Office of the President of the Republic Lithuania (2015): https://www.lrp.lt/lt/spaudos-centras/ pranesimai-spaudai/prezidente-skaitys-sesta-metini-pranesima/22880

Putnam, Robert (1993): Making Democracy Work: Civic Traditions in Modern Italy. Princeton: Princeton University Press.

Ramonaitè, Ainè, et al. (2014): Kaip renkasi Lietuvos rinkejjai? Idejjos, interesai ir ǰvaizdžiai politikoje. Vilnius: Vilniaus universiteto leidykla.

Randma, L. (2001): A Small Civil Service in Transition: The Case of Estonia. Public Administration and Development, 21(1).

Rose, R. - Mishler, W. (2011): Political Trust and Distrust in Post-Authoritarian Contexts, in Zmerli, S. - Hooghe, M., eds., Political Trust. Why Context Matters, 117-140, ECPR Press.

Rothstein, Bo (2011): The Quality of Government: Corruption, Social Trust, and Inequality in International Perspective. Chicago: University of Chicago Press.

Rothstein, Bo - Stolle, Dietlind (2008): The State and Social Capital: An Institutional Theory of Generalized Trust. Comparative Politics, 40 (4)(Jul., 2008): 441-459.

Sarapuu, K. (2012): Administrative Structure in Times of Changes: The Development of Estonian Ministries and Government Agencies 1990-2010. International Journal of Public Administration 35.

Steen, Anton (1996): Confidence in Institutions in Post-Communist Societies: The Case of the Baltic States, Scandinavian Political Studies 19 (3): 205-224.

Svallofors, Stefan (2013): Government quality, egalitarianism, and attitudes to taxes and social spending: A European comparison. European Political Science Review 5(3): 363-380.

Titma, M. et al. (1998): Winners and losers in the postcommunist transition: New evidence from Estonia. Post-Soviet Affairs 14(2): 114-136.

Tõnnisson, Kristiina - Randma-Liiv, Tiina (2008): Public Management Reforms: Estonia, in Bouckaert, G. - Nemec, J. - Nakrošis, V. - Hajnal, G. - Tõnnisson, K. eds. Public Management Reforms in Central and Eastern Europe, 93-120, Bratislava, Slovakia: NISPAcee.

United Nations (2015): Human Development Report 2015: available at http://hdr.undp.org/ en/2015-report.

Uslaner, Eric M. (2008): Corruption, Inequality, and the Rule of Law: The Bulging Pocket Makes the Easy Life. Cambridge: Cambridge University Press.

Uslaner, Eric M. (2009): Corruption, in Svendsen, Gert Tinggaard - Svendsen, Gunnar Lind Haase, eds., Handbook of Social Capital: The Troika of Sociology, Political Science and Economics. Cheltenham \& Northhampton: Edward Elgar.

Liutauras Gudžinskas is Associate Professor at the Institute of International Relations and Political Science (Vilnius University). Email: liutauras.gudzinskas@ tspmi.vu.lt. 